\title{
Neurosyphilis concurrently involving eye and ear
}

\author{
Futoshi Nakagami, ${ }^{1}$ Hideharu Hagiya, ${ }^{1}$ Kazuichi Maruyama ${ }_{1}^{2}$ Yuri Onishi ${ }^{1}$
}

${ }^{1}$ Department of General Internal Medicine, Osaka University Hospital, Suita, Japan ${ }^{2}$ Department of Innovative Visual Science, Osaka University Hospital, Suita, Japan

Correspondence to Dr Hideharu Hagiya, e_dai_for_all@hotmail.com

Accepted 24 September 2018

\section{DESCRIPTION}

A 42-year-old woman presented to our hospital with a 2-month history of bilateral decreased and blurry vision accompanying mild photophobia. She had had several episodes of unsafe sex and was diagnosed with secondary syphilis 10 months prior. Despite the diagnosis, she did not undergo any treatment for the infection. An ophthalmological examination revealed bilateral macular oedema, suggesting the development of uveitis (figure 1A,B). Laboratory data for complete blood counts and chemistry were unremarkable, but there were elevations of rapid plasma reagin (RPR) test and Treponema pallidum haemagglutination test (TPHA) titres, at 1:32 and 1:5120, respectively, leading to the diagnosis of ocular syphilis. Screening tests for hepatitis B virus, hepatitis $\mathrm{C}$ virus and HIV yielded negative findings. Further cerebrospinal fluid examination indicated a complication of neurosyphilis, with a mildly elevated white cell count $\left(0.013 \times 10^{9} / \mathrm{L}\right)$, protein level $(49 \mathrm{mg} /$ $\mathrm{dL})$, and positive RPR (1:4) and TPHA (1:320) titres. The patient was scheduled to be hospitalised in order to undergo intravenous treatment. Before admission, the patient suddenly experienced hearing deficit. The Weber test showed lateralisation to the right ear and the Rinne test was positive in the left ear,
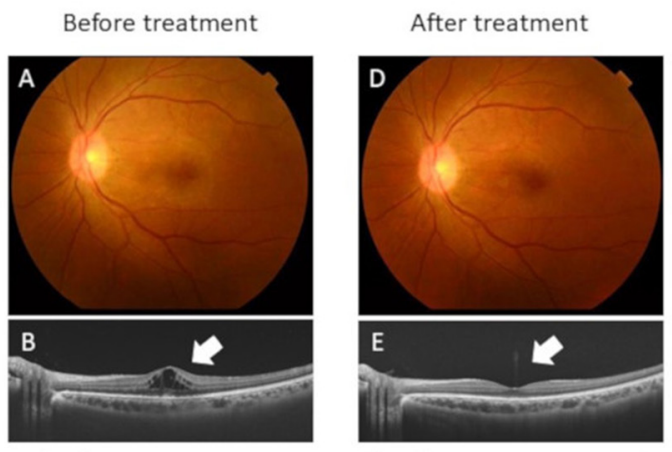

Check for updates

(C) BMJ Publishing Group Limited 2018. No commercial re-use. See rights and permissions. Published by BMJ.

\begin{tabular}{|l|}
\hline To cite: Nakagami F, \\
Hagiya H, Maruyama K, et al. \\
BMJ Case Rep Published \\
Online First: [please \\
include Day Month Year]. \\
doi:10.1136/bcr-2018- \\
227185 \\
\hline
\end{tabular}
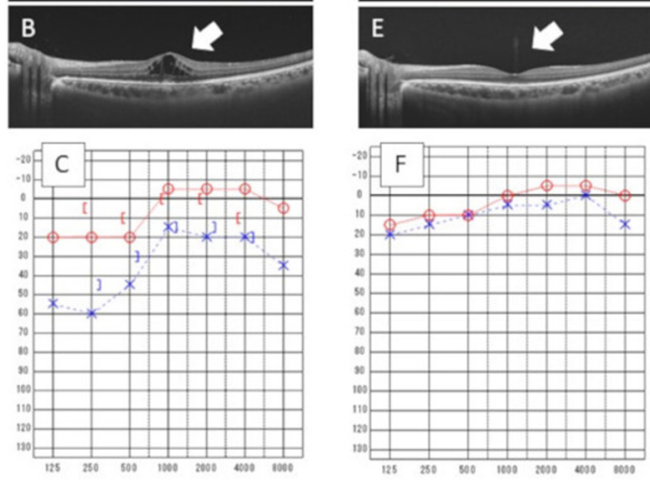

Figure 1 Fundus photograph, optical coherence tomography and audiogram. White colour appearance observed inside the vascular arcade before treatment (A) disappeared 1 month after treatment (D). Optical coherence tomography showed a decrease in macular oedema and resolution of the loss of ellipsoid zone $(B, E$; arrow). Auditory function also improved after treatment $(C, F)$. suggesting a left sensorineural hearing deficit, which was proven by an audiogram (figure 1C). Brain MRI did not show any remarkable findings in her brain. Having been diagnosed with ocular and otosyphilis, we administered aqueous penicillin G (24 million units per day) along with prednisone $(0.5 \mathrm{mg} / \mathrm{kg})$. After completing 14 days of antibiotic therapy, the patient was discharged without any complications. Her visual symptoms improved, and macular oedema and loss of ellipsoid zone were dramatically improved (figure 1D,E). The auditory dysfunction resolved as well (figure 1F). After 4 months of treatment, serum titres of RPR decreased to 1:8.

Syphilis, a classical sexually transmitted infection caused by Treponema pallidum, has globally re-emerged as a silent pathogen, reaching up to more than 4000 cases in 2016 in Japan. ${ }^{1}$ Although typical manifestations of the disease include genital and dermatological symptoms, the infection potentially causes systemic abnormalities. Neurosyphilis is the representative condition, which commonly occurs at a late stage (more than 1 year) of the infection. Concurrent complications of ocular and auditory dysfunction are considered extremely rare, ${ }^{23}$ although an exact prevalence of such a condition is unknown. Reviewing the patient's clinical course, she developed the ocular and otosyphilis at almost 1 year after infection with the pathogen. General physicians should recall that syphilis is a possible aetiology of multiple cranial nerve manifestations.

\section{Learning points}

- Syphilis, a re-emerging silent pathogen, potentially causes various manifestations during the course of infection.

- This case highlights the concurrent development of ocular and otosyphilis almost 1 year after infection.
Acknowledgements We are grateful to Hiromi Rakugi (Department of General Internal Medicine, Osaka University Hospital) for his advice and warm encouragement.

Contributors All the authors contributed management of the patient and writing of this report. Especially, FN, KM and YO mainly managed the patient. $\mathrm{HH}$ mainly wrote the manuscript.

Funding The authors have not declared a specific grant for this research from any funding agency in the public, commercial or not-for-profit sectors.

Competing interests None declared.

Patient consent Obtained.

Provenance and peer review Not commissioned; externally peer reviewed. 


\section{REFERENCES}

1 Takahashi T, Arima Y, Yamagishi T, et al. Rapid increase in reports of Syphilis associated with men who have sex with women and women who have sex with Men, Japan, 2012 to 2016. Sex Transm Dis 2018;45:139-43.
2 Papalini C, Cagini C, Ricci G, et al. Ocular and oto-syphilis: not a thing of the past. Infection 2017:45:725-6.

3 Eliott D, Papaliodis GN, Durand ML, et al. A 50-Year-Old man with cloudy vision, hearing loss, and unsteadiness. N Engl J Med 2016;374:2586-93.

Copyright 2018 BMJ Publishing Group. All rights reserved. For permission to reuse any of this content visit

http://group.bmj.com/group/rights-licensing/permissions.

BMJ Case Report Fellows may re-use this article for personal use and teaching without any further permission.

Become a Fellow of BMJ Case Reports today and you can:

- Submit as many cases as you like

- Enjoy fast sympathetic peer review and rapid publication of accepted articles

- Access all the published articles

- Re-use any of the published material for personal use and teaching without further permission

For information on Institutional Fellowships contact consortiasales@bmjgroup.com

Visit casereports.bmj.com for more articles like this and to become a Fellow 